This is an Open Access article under the CC BY-SA license (http://creativecommons.org/licenses/by-sa/4.0/)

\title{
PERAN PERAWAT SEBAGAI EDUCATOR MEMPENGARUHI KEPATUHAN KONSUMSI OBAT ANTIRETROVIRAL (ARV) BAGI PASIEN HIV/AIDS DI KLINIK VCT RSUD Dr. MOEWARDI (Nurse Role As Educator Affected the Compliance of Antiretroviral (ARV) Consumption For Patients with HIVIAIDS in the VCT Clinic of Dr. Moewardi Hospital)
}

\author{
Danik Astuti dan Mulyaningsih \\ Stikes 'Aisyiyah Surakarta \\ email: ningsih.solo@gmail.com
}

\begin{abstract}
HIV/AIDS is a global matter, it threatens the world including Indonesia. Antiretroviral (ARV) is a therapy which patients have to consume medicine for their life, antiretroviral (ARV) therapy is able to make relieved to ODHA (HIV/AIDS patient) and family. Nurse participation is most needed by patients in doing therapy process. The aim of this study was to know and analyze the correlation of nurses as educator by the compliance of antiretroviral medicine consumption to HIV/AIDS patients in VCT clinic of Dr. Moewardi hospital. This research used cross sectional approach. The research subjects were HIV/AIDS patients which undergone antiretroviral (ARV) therapy in VCT clinic of Dr. Moewardi hospital by 65 respondents as sample. The research instruments used questionnaire and follow-up card. The data analysis used chi square test. Result;Univariat analysis outcome was known by most of respondents to perceive nurses participation as educator in good category (58,5\%) and most of them are obedient in consuming antiretroviral (ARV) medicine (52,3\%). Bivariat analysis outcome was the chi square score to significant extend $5 \%$ as 6,665 by pvalue 0,010 and odd ratio $(O R)$ as mush as 3,846 CI 95\% (1.354-10.922). There was significant correlation between nurses as educator and the compliance of antiretroviral (ARV) medicine consumption in VCT clinic of Dr. Moewardi hospital.
\end{abstract}

Keywords: nurses participation, obedience, patient

\begin{abstract}
Abstrak: Masalah HIV/AIDS merupakan masalah kesehatan global yang mengancam dunia termasuk Indonesia. Terapi antiretroviral (ARV) merupakan terapi yang dijalankan pasien dengan mengkonsumsi obat seumur hidup mereka, adanya terapi antiretroviral (ARV) merupakan payung peneduh bagi ODHA dan keluarga. Peran serta perawat sangat dibutuhkan oleh pasien dalam menjalani terapi. Tujuan penelitian ini adalah untuk mengetahui dan menganalisa hubungan perawat sebagai educator dengan kepatuhan konsumsi obat antiretroviral (ARV) bagi pasien HIV/AIDS di klinik VCT RSUD Dr. Moewardi. Desain penelitian dengan pendekatan cross sectional. Subjek penelitian adalah pasien HIV/AIDS yang melakukan terapi antiretroviral (ARV) di klinik VCT RSUD Dr. Moewardi dengan sampel sebanyak 65 responden. Instrumen penelitian berupa kuisioner dan kartu follow-up. Teknik analisa data menggunakan uji chi square. Hasil analisa univariat diketahui sebagian besar responden mempersepsikan peran perawat sebagai educator dalam kategori baik $(58,5 \%)$ dan sebagian besar responden patuh dalam mengkonsumsi obat antiretroviral (ARV) (52,3\%). Hasil analisa bivariat diperoleh nilai chi square untuk taraf signifikan 5\% sebesar 6,665 dengan $\rho_{\text {value }} 0,010$ dan odd ratio (OR) sebesar 3,846 CI 95\% (1.354-10.922). Kesimpulan; ada hubungan yang signifikan antara peran perawat sebagai educator dengan kepatuhan konsumsi obat antiretroviral (ARV) di klinik VCT RSUD Dr. Moewardi.
\end{abstract}

Kata Kunci: peran perawat, kepatuhan, pasien 
Masalah HIV/AIDS merupakan masalah kesehatan global yang mengancam dunia termasuk Indonesia. Masalah yang berkembang sehubungan dengan penyakit HIV dan AIDS adalah angka kejadian dan kematian yang masih tinggi. Saat ini tidak ada negara yang terbebas dari masalah HIV/AIDS. Meskipun telah dicapai berbagai kemajuan di bidang kedokteran dan farmasi, serta telah dilakukan berbagai upaya pencegahan primer maupun sekunder, tetapi angka kesakitan dan kematian tetap tinggi (Nasronudin, 2014).

Angka kematian tertinggi di Indonesia salah satunya adalah masalah HIV/AIDS. Sejak tahun 2005 sampai September 2015 terdapat kasus HIV sebanyak 184.929 yang didapat dari laporan layanan konseling dan tes HIV. Jumlah kasus HIV tertinggi yaitu di DKI Jakarta (38.464 kasus), diikuti Jawa Timur (24.104 kasus), Papua (20.147 kasus), Jawa Barat (17.075 kasus), dan Jawa Tengah (12.267 kasus). Sementara kasus AIDS sampai September 2015 sejumlah 68.917 kasus. Sampai September 2015 kasus AIDS terbesar di 381 (77 persen) dari 498 kabupaten/kota di seluruhprovinsi di Indonesia. Di Surakarta kasus HIV AIDS selalu mengalami kenaikan setiap tahunnya. Dan pada tahun 2015 mencapai 1.738 kasus. Tingginya angka penderita HIV/AIDS di Kota Surakarta tersebut menduduki peringkat kedua setelah Kota Semarang (Kemenkes, 2015).

Upaya pemerintah yang telah dilakukan untuk menurunkan angka penderita HIV/AIDS yaitu melalui terapi antiretroviral. Terapi tersebut merupakan terapi yang dijalankan pasien dengan mengonsumsi obat seumur hidup mereka. Untuk menekan penggandaan (replikasi) virus di dalam darah, tingkat obat antiretroviral harus selalu di atas tingkat tertentu. Pemberian terapi ARV tidak serta merta diberikan begitu saja pada penderita yang dicurigai tetapi perlu mempertimbangkan berbagai faktor dari segi pengetahuan, kemampuan, kesanggupan pengobatan jangka panjang, resistensi obat, efek samping, jangkauan memperoleh obat, serta saat yang tepat untuk memulai terapi. Dengan semakin dekat dan mudahnya antiretroviral (ARV) dijangkau masyarakat, maka langkah mantap dari pemerintah tersebut merupakan payung peneduh bagi ODHA dan keluarga (Nasronudin, 2007).

Data ODHA di Indonesia yang mendapatkan pengobatan ARV sampai dengan bulan Maret 2014 sebanyak 25.817 orang. Sebanyak $96 \%$ orang dewasa dan $4 \%$ anak-anak. Sedangkan pemakaian rejimennya adalah 95,6\% (27.134 orang) menggunakan lini 1 dan 4,5\% (1.249 orang) menggunakan lini 2. Data tahun 2015 di klinik VCT terdapat 192 penderita HIV/AIDS dan ODHA yang melakukan terapi ARV sebanyak 187 penderita. Dari 187 penderita yang patuh mengkonsumsi obat antiretroviral sebanyak 167 penderita sedangkan yang tidak patuh sebanyak 20 penderita (Kementrian RI, 2015).

Hasil wawancara mendalam dan observasi sebagian besar tingkat kepatuhan ODHA minum obat ARV adalah $>95 \%$. Hal ini disebabkan adanya dukungan dari keluarga (orang tua dan suami), teman, Manager kasus dan faktor motivasi dalam diri ODHA seperti untuk tetap hidup dan melakukan aktifitas dengan baik. Hasil penelitian ini menunjukkan bahwa dengan adanya kunjungan manajer kasus selama 3 sampai 4 kali kunjungan menunjukkan kepatuhan minum obat $>95 \%$ (Yuniar, 2013).

Hasil penelitian Afidah (2013) mengatakan bahwa perawat diharapkan dapat mengoptimalkan perannya sebagai yaitu dengan memberikan informasi yang dibutuhkan oleh pasien, menjadi penghubung antara pasien dan tim kesehatan lain, membela hak-hak pasien dan melindungi pasien dari tindakan yang merugikan perawat atau tim kesehatan lain seharusnya dapat memberikan sasaran mengenai pengobatandan proses kesembuhannya. merugikan. Saran yang diberikan dapat mengurangi kecemasan yang dialami pasien sehingga dapat menunjang keberhasilan pengobatan selanjutnya.

Hasil penelitian Hapsari (2013) menunjukkan jumlah responden dengan kategori tidak mendapatkan peran perawat sebagai educator dengan baik sebanyak 48 responden $(64,0 \%)$ dan jumlah responden dengan kategori mendapatkan pelaksanaan peran perawat sebagai educator dengan baik sebanyak 27 responden $(36,0 \%)$. Hasil penelitian pada 75 pasien menggambarkan sebagian besar reponden belum mendapatkan peran perawat sebagai educator. Perawat pada dasarnya memiliki tiga peran dalam melaksanakan tugasnya. Peran mandiri, peran tergantung dan peran kolaborasi merupakan peran perawat dalam memberikan pelayanan kesehatan pada pasien.

Hasil penelitian Hapsari (2013) menunjukkan bahwa hampir $50 \%$ responden menilai peran perawat sebagai educator dalam kategori tidak baik. Faktor lain yang mempengaruhi peran perawat sebagai educator adalah kondisi pasien, kebudayaan pasien, bahasa yang digunakan pasien sehari-hari dan kesiapan pasien/keluarga dalam menerima pengajaran dari perawat. 
Berdasarkan dari hasil wawancara dengan pasien yang melakukan terapi antiretroviral di dapatkan hasil 5 dari 10 responden diantaranya menjawab peran perawat kurang baik dalam memberikan pelayanan. Dan dari 10 responden didapatkan hasil 6 diantaranya menyatakan tidak patuh dan 4 diantaranya patuh. 3 dari responden mengatakan tidak patuh karena perawatnya kurang care dalam memberikan pelayanan.

Berdasarkan latar belakang masalah yang telah diuraikan di atas maka rumusan masalah yang ditetapkan yaitu apakah ada hubungan peran perawat sebagai educator dengan kepatuhan konsumsi obat antiretroviral (ARV) bagi pasien HIV/AIDS di klinik VCT RSUD Dr. Moewardi. Penelitian dilakukan untuk mengetahui hubungan peran perawat sebagai educator dengan kepatuhan konsumsi obat antiretroviral (ARV) bagi pasien HIV/AIDS di klinik VCT RSUD Dr. Moewardi.

\section{BAHAN DAN METODE}

Penelitian ini merupakan penelitian dengan pendekatan cross sectional. Metode penelitian ini adalah analitik dimana mencoba mencari hubungan antara variable dan seberapa besar hubungan antara variabel yang ada. Lokasi penelitian di ruang voluntary counseling and testing (VCT) RSUD Dr. Moewardi. Populasi yang digunakan dalam penelitian ini adalah seluruh pasien HIV/AIDS yang melakukan terapi antiretroviral (ARV) di VCT RSUD Dr. Moewardi sebanyak 187 pasien. Sampel yang digunakan sebanyak 65 responden dengan teknik pengambilan sampel accidental sampling. Instrumen yang digunakan berupa lembar kuisioner dan kartu follow up pasien. Data yang dikumpulkan dalam penelitian ini adalah data primer dan data sekunder.Teknik analisa penelitian menggunakan teknik analisa univariat dan analisa bivariat dengan uji Chi Square.

\section{HASIL PENELITIAN}

\section{Perawat Sebagai Educator}

Tabel 1. Distribusi Frekuensi Peran Perawat Sebagai Educator Di Klinik VCT RSUD Dr. Moewardi

\begin{tabular}{llcc}
\hline No & $\begin{array}{c}\text { Peran perawat } \\
\text { sebagai educator }\end{array}$ & f & $\%$ \\
\hline 1 & Kurang baik & 27 & 41,5 \\
2 & Baik & 38 & 58,5 \\
\hline & Total & 65 & 100 \\
\hline
\end{tabular}

Berdasarkan tabel 1 menunjukkan bahwa dari 65 responden sebanyak 38 responden $(58,5 \%)$ mempersepsikan peran perawat sebagai educator dalam kategori baik.

Dalam menjalankan peran educator perawat membantu pasien untuk meningkatkan kesehatannya melalui pemberian pengetahuan terkait dengan keperawatan dan tindakan medis yang diterima sehingga pasien atau keluarga dapat menerima tanggung jawab terhadap hal-hal yang diketahuinya

Hasil penelitian yang dilakukan oleh Hapsari (2013) faktor yang dapat mempengaruhi peran perawat sebagai educator adalah kondisi pasien, kebudayaan pasien, bahasa yang digunakan pasien seharihari dan kesiapan pasien/keluarga pasien dalam menerima pengajaran dari perawat. Hal ini didukung oleh pernyataan Erickson yang mengatakan bahwa hal yang dapat mempengaruhi peran perawat sebagai educator di rumah sakit adalah bahasa dan kebudayaan pasien.

Hasil penelitian Hapsari (2013) menunjukkan bahwa $50 \%$ responden menilai peran perawat sebagai educator kategori tidak baik. Ada faktor lain yang mempengaruhi pelaksanaan peran perawat sebagai educator antara lain usia, pendidikan, lama kerja, pengetahuan dan sikap mengambil bagian penting yang biasa mempengaruhi pelaksanaan peran perawat sebagai educator di rumah sakit. Perawat sebagai educator di rumah sakit mempunyai peran dan tanggung jawab yang besar.

\section{Kepatuhan Konsumsi Obat Antiretroviral}

Tabel 2. Distribusi Frekuensi Kepatuhan Konsumsi Obat Antiretroviral (ARV) Bagi Pasien HIV/ AIDS Di Klinik VCT RSUD Dr. Moewardi

\begin{tabular}{clcc}
\hline No & $\begin{array}{c}\text { Kepatuhan } \\
\text { Konsusmsi } \\
\text { ARV }\end{array}$ & f & \% \\
\hline 1 & Patuh & 31 & 47,7 \\
2 & Tidak Patuh & 34 & 52,3 \\
\hline & Total & 65 & 100 \\
\hline
\end{tabular}

Berdasarkan tabel 2 menunjukkan bahwa dari 65 responden sebanyak 34 responden $(52,3 \%)$ patuh dalam mengkonsumsi obat antiretroviral (ARV).

Obat antiretroviral mempunyai peranan penting bagi pasien HIV/AIDS yaitu untuk memperpanjang usia dan memperbaiki kualitas hidup Kepatuhan menggunakan obat antiretroviral merupakan motivasi dari dalam diri penderita untuk tetap bertahan 
hidup, tingkat kesadaran tinggi akan fungsi dan manfaat ARV serta keimanan terhadap agama/keyakinannya. Motivasi dari dalam diri penderita untuk sembuh atau bertahan hidup merupakan faktor pendukung kepatuhan yang paling sering dinyatakan oleh responden.

Menurut Nasronudin (2007) kepatuhan pasien dalam mengkonsumsi obat antiretroviral dipengaruhi oleh banyak faktor, pengelolaan dan perawatan terhadap penderita HIV/AIDS tergantung pada kerjasama petugas kesehatan dengan pasien keluarga. ODHA yang mempunyai pengetahuan yang cukup tentang HIV/AIDS, kemudian selanjutnya mengubah perilakunya sehingga akan dapat mengendalikan kondisi penyakitnya, sehingga penerita dapat hidup lebih lama. Konseling sangat dibutuhkan untuk memberikan pengetahuan terhadap ODHA dan penerimaan pasien terhadap sakitnya. Pengetahuan itu meliputi pengertian tentang terapi ARV, pentingnya kepatuhan terapi, efek samping yang mungkin terjadi serta lama, dengan pengetahuan tinggi diharapkan ODHA menjalankan kepatuhan terapi ARV sesuai aturan yang dianjurkan oleh dokter. Hasil penelitian sejalan dengan penelitian yang dialakukan oleh Mahardining (2012) sebagian patuh menggunakan obat antiretroviral dipengaruhi dukungan dari anggota keluarga dan teman dekat merupakan salah satu dukungan yang sangat diperlukan terhadap pelaksanaan terapi ARV dan berpengaruh besar bagi ODHA untuk memacu semangat hidupnya.

Menurut hasil penelitian Yuniar (2013) menjelaskan bahwa faktor eksternal utama yang meningkatkan kepatuhan minum ARV adalah 1) ketersediaan dan keterjangkauan obat ARV, dukungan keluarga, KDS, LSM dan tenaga kesehatan serta destigmatisasi dan tidak boleh ada diskriminasi oleh teman, masyarakat dan tenaga kesehatan. 2) meningkatkan keterlibatan keluarga, KDS, LSM dan tenaga kesehatan untuk memotivasi ODHA agar hidup lebih berkualitas dan minum ARV secara teratur. Meningkatkan akses dan keterjangkauan biaya pemeriksaan laboratorium dan obat-obat IO (Infeksi Oportunistik). 3) meningkatkan edukasi ke masyarakat untuk mengurangi atau menghilangkan stigma dan diskriminasi terhadap ODHA, meningkatkan kepedulian terhadap ODHA khususnya ODHA anak-anak.

\section{Analisa Bivariat Hubungan peran perawat sebagai educator dengan kepatuhan konsumsi obat antiretroviral (ARV) bagi pasien HIV/ AIDS di klinik VCT RSUD Dr.Moewardi}

Berdasarkan Tabel 3 di atas dapat diketahui bahwa responden yang berpersepsi peran perawat baik dan patuh yaitu sebanyak 25 responden $(38,5 \%)$. Untuk persepsi peran perawat kurang baik dan tidak patuh sebanyak 18 responden $(27,7 \%)$.

Setelah dilakukan analisa dengan uji Chi Square, dari hasil tersebut dapat disimpulkan ada hubungan yang signifikan antara peran perawat sebagai educator dengan kepatuhan konsumsi obat antiretroviral (ARV) di klinik VCT RSUD Dr. Moewardi dengan $\rho_{\text {value }} 0,010$. Nilai OR 3,846 artinya bahwa peran perawat sebagai educator yang baik mempunyai peluang 3,846 kali pasien untuk patuh mengkonsumsi ARV dibandingkan dengan peran kurang baik dari perawat dalam memberi edukasi kepatuhan konsumsi obat antiretroviral (ARV).

\section{PEMBAHASAN}

Hasil penelitian ini sejalan dengan hasil penelitian yang telah dilakukan oleh Lumbanbantu (2012) dimana peran serta perawat sangat dibutuhkan oleh pasien karena dengan adanya dukungan dan pengarahan dari perawat akan memberikan semangat bagi pasien HIV/AIDS untuk menjalani terapi antiretroviral dengan patuh.

Menurut Susanto (2012) perawat sebagai educator harus memberikan pengetahuan, informasi,

Tabel 3. Hubungan peran perawat sebagai educator dengan kepatuhan konsumsi obat antiretroviral (ARV) bagi pasien HIV/AIDS di klinik VCT RSUD Dr. Moewardi

\begin{tabular}{|c|c|c|c|c|c|c|c|c|}
\hline \multirow{3}{*}{$\begin{array}{c}\text { Peran } \\
\text { perawat } \\
\text { sebagai } \\
\text { educator }\end{array}$} & \multirow{2}{*}{\multicolumn{2}{|c|}{$\begin{array}{c}\text { Kepatuhan } \\
\text { Tidak patuh }\end{array}$}} & \multirow{2}{*}{\multicolumn{2}{|c|}{ Patuh }} & \multirow[b]{2}{*}{ Total } & \multirow[b]{3}{*}{$\rho_{\text {value }}$} & \multirow{3}{*}{ OR } & \multirow{3}{*}{$\begin{array}{l}\text { CI 95\% } \\
\text { Lower } \\
\text { upper }\end{array}$} \\
\hline & & & & & & & & \\
\hline & f & $\%$ & \multicolumn{2}{|c|}{ f $\%$} & f $\%$ & & & \\
\hline Kurang B aik & 18 & 27,7 & 9 & 13,8 & 2741,5 & 0,010 & 3,846 & $\begin{array}{l}1.354 \\
10.922\end{array}$ \\
\hline Baik & 13 & 20 & 25 & 38,5 & 3858,5 & & & \\
\hline Total & 34 & 47,7 & 31 & 52,3 & $\begin{array}{ll}65 & 100\end{array}$ & & & \\
\hline
\end{tabular}


dan pelatihan ketrampilan kepada pasien, keluarga pasien maupun anggota masyarakat dalam upaya pencegahan penyakit dan peningkatan kesehatan. Dalam memberikan pengetahuan atau pendidikan perawat harus mampu mempengaruhi pasien agar dapat berperilaku atau memiliki pengetahuan dan pemahaman yang sesuai dengan yang diharapkan sehingga pasien dapat mempunyai semangat yang tinggi pula untuk menjalani terapi antiretroviral (ARV).

Hasil penelitian Martoni (2013) salah satu faktor yang mempengaruhi tingkat kepatuhan adalah pengetahuan terapi pasien. Penetahuan merupakan faktor yang paling dominan berhubungan dengan kepatuhan pasien HIV/AIDS terhadap terapi ARV. Dengan adanya pengetahuan yang tinggi dari pasien akan mempengaruhi tingkat kepatuhan yang tinggi pula dari pasien. Dengan pengetahuan yang cukup tentang HIV/AIDS pasien akan merubah perilakunya sehingga akan dapat mengendalikan kondisi penyakitnya Selain itu pemberian pendidikan terhadap pasien akan mempengaruhi pengetahuan pasien sehingga pasien mempunyai semangat yang tinggi untuk lebih patuh dalam menjalani terapi antiretroviral (ARV).

Menurut Niven (2000) dan Carpentino (2009) adanya pemberian pendidikan yang aktif dari perawat seperti penggunaan buku-buku, leaflet, dan lembar balik akan mampu meningkatkan kepatuhan pasien. Temuan ini didukung oleh pernyataan Meichenbuan \& Turk, bahwa faktor yang paling berhubungan dengan kepatuhan antara lain faktor sikap, keadaan sakit yang dirasakan, faktor lingkungan dan faktor psikis. Hal ini sejalan dengan Nasronudin dan Margarita (2007) berhasilnya pengelolaan dan perawatan terhadap penderita HIV/AIDS tergantung pada kerjasama petugas kesehatan dengan pasien.

Fisher (1992 dalam Bastable, 2002) mengemukakan bahwa perspektif ahli farmasi terhadap pengukuran kepatuhan yang dilakukan pada program pengobatan lebih efektif dengan model komunikasi untuk pendidikan yang diberikan kepada pasien. Komunikasi antara perawat dan pasien/ keluarga dalam pendidikan kesehatan sangat penting dalam memudahkan pasien dalam menerima atau memahami instruksi yang diberikan untuk pasien ketika berada di rumah yang dapat secara mandiri menjaga atau meningkatkan kesehatannya. Komunikasi yang efektif juga akan meningkatkan kepatuhan pada pasien. Jadi peran serta perawat sangat mempengaruhi kepatuhan konsumsi obat antiretroviral bagi pasien HIV/AIDS.

Menurut Asmadi (2008) Kemampuan berkomunikasi perawat merupakan aspek mendasar dalam keperawatan. Perawat harus berinteraksi dengan pasien selama 24 jam penuh. Interaksi merupakan bagian dari komunikasi. Perawat dapat memberikan informasi/penjelasan kepada pasien, membujuk dan menghibur pasien, dan menjalankan tugas lainnya dengan adanya komunikasi. Proses komunikasi diharapakan dapat mempengaruhi dan meyakinkan pihak lain baik itu pasien, rekan sejawat, maupun tenaga kesehatan lain. Citra profesionalisme yang baik pada perawat akan tercipta dengan komunikasi yang baik pula.

Perawat harus mampu memahami psikologis pasien agar dapat mempengaruhi orang lain. Perawat harus meningkatkan sensitivitas dan kepeduliannya. Saat berbicara dengan orang lain perawat harus melakukannya dengan hati dengan kata lain perawat berkomunikasi dengan orang lain dengan menyentuh hati orang lain. Seberapa bagusnya gaya komunikasi perawat dan luasnya wawasan ilmu pengetahuan, orang lain perlu melihat bukti atas apa yang disampaikan. Upaya untuk mengubah dan meningkatkan profesionalisme perawat paling baik dilakukan melalui pembuktian secara langsung melalui peran sebagai model.

Menurut Asmadi (2008) dengan adanya model atau contoh hal ini berarti bisa membangun dukungan sosial dari keluarga dan teman-teman. Selain itu kelompok-kelompok pendukung dapat dibentuk untuk membantu kepatuhan terhadap programprogram pengobatan seperti pengurangan berat badan, berhenti merokok, dan menurunkan konsumsi alkohol sehingga akan mempengaruhi pasien tersebut.

Hasil penelitian lain dari Yuniar (2013) menjelaskan sebagian besar faktor internal utama yang meningkatkan kepatuahan minum ARV adalah motivasi dari dalam diri ODHA untuk lebih berkualitas, pemahaman dan kesadaran yang tinggi akan fungsi dan manfaat ARV, strategi menganggap obat sebagai vitamin atau obat biasa seperti obat darah tinggi atau diabetes.

Hasil penelitian ini juga menemukan fenomena, ada sebagian peran perawat baik tetapi responden tidak patuh dalam mengkonsumsi obat antiretroviral. Ketidak patuhan ini bisa disebabkan faktor individu, seperti lama pengobatan, kondisi psikologis, dan nutrisi yang tidak mendukung. 
Adapun faktor-faktor lain yang bisa menghambat kepatuhan antara lain (Blevins \& Lubkin, 1999; Hussey \& Gilliland, 1989 dalam Carpenito, 2009): 1) penjelasan yang tidak adekuat. Penjelasan yang tidak adekuat dari perawat akan menjadikan pasien semakin binggung dan tidak mengerti terhadap apa yang disampaikan oleh perawat. 2) perbedaan pendapat antara pasien dan tenaga kesehatan. 3) terapi jangka panjang. Obat antiretroviral merupakan jenis obat yang harus dikonsumsi jangka panjang karena obat tersebut merupakan obat yang harus dikonsumsi seumur hidup oleh pasien dengan adanya terapi dalamjangka panjang otomatis akan menimbulkan rasa kebosanan dari pasien tersebut sehingga akan menyebabkan adanya putus obat dari pasien. 4) tingginya kompleksitas atau biaya pengobatan. 5) tingginya jumlah dan tingkat keparahan efek samping.

Menurut Nursalam dan Kurniawati (2007) faktor-faktor yang mempengaruhi kepatuhan terapi adalah malabsobsi obat, interaksi antar obat, resistensi virus. ARV hanya obat yang bersifat semantara dan tidak menyembuhkan penyakit mereka. Pemaknaan ARV sebagai vitamin membuat mereka merasa sehat seperti fungsi vitamin yaitu untuk meningkatkan daya tahan tubuh. Apabila tidak ditunjang dengan pemberian nutrisi yang baik, tingkat kepatuhan menurun ditambah lagi dengan efek samping yang ditimbulkannya.

\section{SIMPULAN DAN SARAN}

\section{Simpulan}

Berdasarkan hasil penelitian yang telah diuraikan sebelumnya, maka dapat diambil kesimpulan bahwa sebagian besar responden mempersepsikan peran perawat sebagai educator baik dan sebagian besar responden patuh dalam mengkonsumsi obat antiretroviral (ARV).

Berdasarkan analisis yang dilakukan diperoleh hasil adanya hubungan peran perawat sebagai educator dengan kepatuhan konsumsi obat antiretroviral (ARV) bagi pasien HIV/AIDS di klinik VCT RSUD Dr. Moewardi.

\section{Saran}

Berdasarkan hasil penelitian yang telah diuraikan diharapkan perawat rumah sakit selalu memberikan semangat atau dorongan kepada pasien HIV/AIDS agar tetap semangat menjalani kehidupannya dan dan selalu memberikan edukasi kepada anggota keluarga agar dari pihak keluarga dapat memotivasi dan mendukung demi kesembuhan pasien dan mengingatkan pasien untuk selalu patuh dalam mengkonsumsi obat antiretroviral (ARV).

\section{DAFTAR RUJUKAN}

Afidah. 2013. "Gambaran Pelaksanaan Peran Advokat Perawat Di Rumah Sakit Negeri Di Kabupaten Semarang".Jurnal Managemen KeperawatanVol 1, No. 2, November 2013: 124-130.

Asmadi. 2008. Konsep Dasar Keperawatan. Jakarta: EGC. Bastable. 2002. Perawat Sebagai Pendidik. Jakarta: EGC. Carpentino. 2009. Diagnosis Keperawatan: Aplikasi Pada Praktik Klinis. Edisi 9. Jakarta: EGC.

Hapsari. 2013.’Hubungan Peran Perawat sebagai Edukator dengan Pemenuhan Kebutuhan Rasa Aman Pasien di Ruang Rawat Inap RSU dr. H. Koesna di Kabupaten Bondowoso". Artikel Ilmiah Mahasiswa 2013.

Kemenkes RI. 2011. Tatalaksana Klinis Infeksi HIV dan Terapi Antiretroviral Pada Orang Dewasa: Jakarta.

Kemenkes. 2015. Artikel Detak Unsiyah.com.

Kurniawati, Nursalam. 2007. Asuhan Keperawatan Pada Pasien Terinfeksi HIV/AIDS. Jakarta: Salemba Medika.

Lumbanbantu. 2012. "Faktor-Faktor Yang Berhubungan Dengan Kepatuhan ODHA (Orang Dengan HiV/ AIDS) Dalam Menjalani Terapi Antiretroviral Di RSU. DR. Pirngadi Medan Tahun 2012”. Artikel Ilmiah Mahasiswa 2012.

Mahardining. 2010. "Hubungan Antara Pengetahuan, Motivasi, Dan Dukungan Keluarga Dengan Kepatuhan Terapi Antiretroviral Pada ODHA". Jurnal Kesehatan Masyarakat.

Martoni. 2013. "Faktor-faktor Yang Mempengaruhi Kepatuhan Pasien HIV/AIDS di Poliklinik Khusus Rawat Jalan Bagian Penyakit Dalam RSUP dr. M. Djamil Padang Periode Desember 2011-Maret 2012”. Jurnal Farmasi Andalas Vol 1 (1) April 2013.

Nasronudin. 2007. Konseling, Dukungan Perawatandan Pengobatan ODHA, Universitas Airlangga: Surabaya.

2014. Konseling, Dukungan Perawatan dan Pengobatan ODHA. Surabaya: Universitas Airlangga.

Niven. 2002. Psikologi Kesehatan Edisi 2. Jakarta: EGC. Susanto. 2012. Buku Ajar Keperawatan Keluarga. Jakarta: Trans Info Media.

Yuniar, Y. 2013. Faktor-Faktor Pendukung Kepatuhan Orang Dengan HIV/AIDS (ODHA) dalam Minum Obat Antiretroviral di Kota Bandung Dan Cimahi. Jurnal Kesehatan. Badan Litbangkes Bandung. 